\title{
Govindjee: a lifetime in photosynthesis
}

\author{
Julian J. Eaton-Rye ${ }^{1}$
}

Received: 13 September 2018 / Accepted: 8 October 2018 / Published online: 31 October 2018

(c) Springer Nature B.V. 2018

Govindjee's outstanding contributions to photosynthesis research and education as well as his magnificent service to the photosynthesis community have been ongoing for over 60 years (Fig. 1). These achievements were recognized at the 8th International Conference on Photosynthesis and Hydrogen Energy Research that was held at the University of Hyderabad (UoH) between October 30 and November 4 in 2017. This meeting, hosted by the Department of Plant Science in the School of Life Sciences at UoH, honored the career of three excellent scientists, Agepati S. Raghavendra, William A. Cramer and Govindjee.

The Hyderabad Conference was in fact held just 6 days after Govindjee's 85th birthday. There have been several earlier celebrations for Govindjee; it is noteworthy that his career was also celebrated in a Special Issue of Photosynthesis Research in 2007 to coincide with his 75th birthday (Eaton-Rye 2007a). Many of Govindjee's past students, postdocs and past collaborators sent in their reminiscences to be included in that special issue (Eaton-Rye 2007b). Further, in 2008, in Indore, India, an international conference was organized to celebrate his career (Jajoo et al. 2009). In addition, for Govindjee's 80th birthday, colleagues from around the world joined to celebrate his contributions and dedication to the photosynthesis research community (Eaton-Rye et al. 2012; Allakhverdiev et al. 2013; Eaton-Rye 2013; Prášil 2014). This culminated in Itoh et al. (2015) and Papageorgiou (2015) dedicating a book on a broad range of topics in photosynthesis research to Govindjee. To mark his 85th birthday, Photosynthetica produced a Special Issue consisting of 45 articles with 167 authors from 20 countries (cf. Garab 2018; see Eaton-Rye 2018); additional recognition of Govindjee at his 85th birthday was held at the University of Udaipur (see Soni 2018; Soni and Kaur 2018). The Hyderabad conference thus joins a long list of events that

Julian J. Eaton-Rye

julian.eaton-rye@otago.ac.nz

1 Department of Biochemistry, University of Otago, Dunedin 9016, New Zealand have recognized Govindjee's outstanding accomplishments (Fig. 2). In addition, his publications from across his career have been summarized by Clegg (2012), Eaton-Rye (2012, 2018) and Papageorgiou (2012).

In his personal perspective in this Special Issue, Govindjee outlines his research journey beginning with his MSc in Botany from the University of Allahabad in 1954, followed by his $\mathrm{PhD}$ studies at the University of Illinois at UrbanaChampaign (UIUC), and his subsequent career at UIUC as Professor of Biochemistry, Biophysics and Plant Biology (retired in 1999) and now Professor Emeritus (Govindjee 2018). In addition to his prolific research career with over 400 publications, Govindjee has been continuously active in supporting all aspects of education in photosynthesis. These activities began with a coauthored basic book on photosynthesis (Rabinowitch and Govindjee 1969), three articles in Scientific American (Rabinowitch and Govindjee 1965; Govindjee and Govindjee 1974; Govindjee and Coleman 1990), four edited books on photosynthesis (Govindjee 1975, 1982a, b; Govindjee et al. 1986), and now a current educational perspective of photosynthesis (Shevela et al. 2018).

In 1994, Govindjee launched the highly successful Advances in Photosynthesis and Respiration Book series serving as its series editor up until 2017 (together with Thomas D. Sharkey from 2012) (see https://www.springer. com/series/5599). Volume 34 of this series (Eaton-Rye et al. 2012) was dedicated to him for his many teaching and other educational contributions. Govindjee was also coeditor of several influential volumes in the series with: (i) Barbara Demmig-Adams, Gyozo Garab and William Adams III on how plants protect themselves against excess light (DemmigAdams et al. 2014); (ii) Agu Laisk and Lada Nedbal (Laisk et al. 2009) on in silico photosynthesis; (iii) Tom Beatty, Howard Gest and John Allen (Govindjee et al. 2006) on discoveries in photosynthesis; and (iv) George Papageorgiou (Papageorgiou and Govindjee 2004) on the use of chlorophyll $a$ fluorescence to understand photosynthesis. It is noteworthy that the Discoveries in Photosynthesis (which 
Fig. 1 Govindjee young at heart. a At the Taj Mahal in the mid-2000s and b looking to the future at ca. 2 years of age
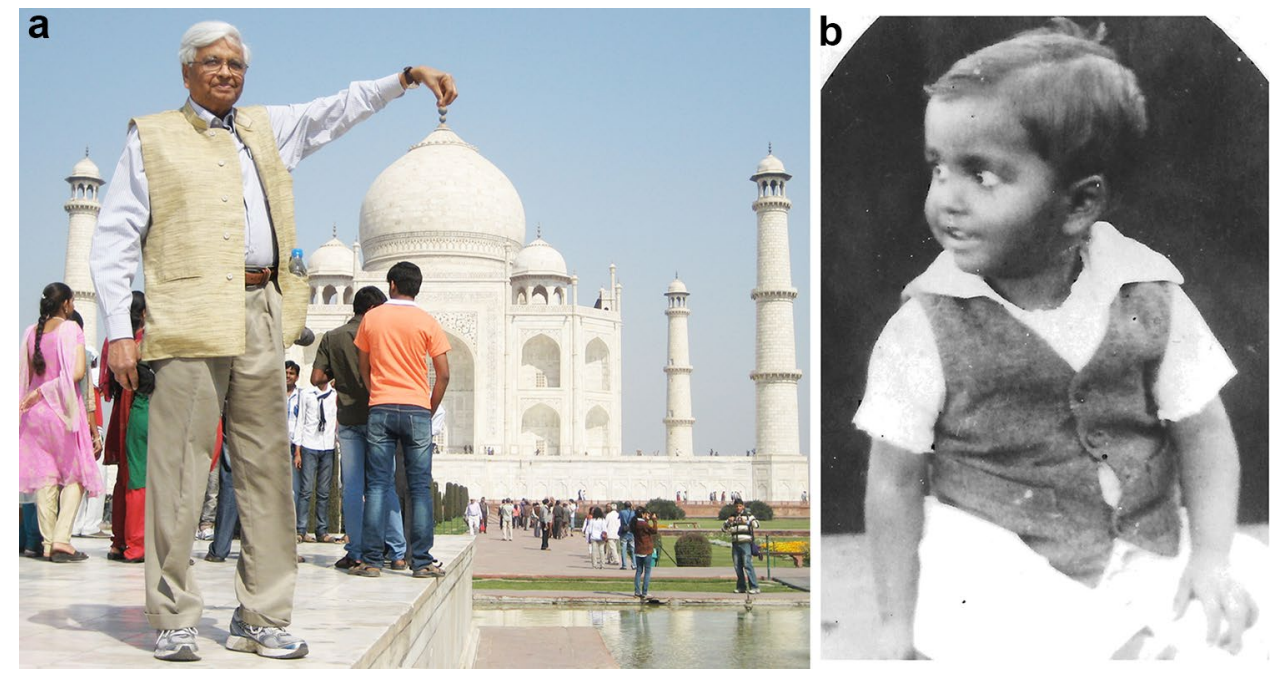

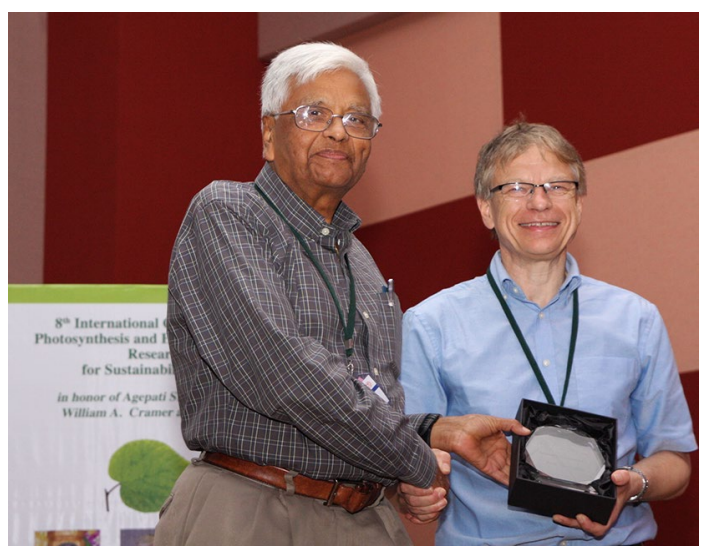

Fig. 2 Govindjee receiving a plaque in recognition of his outstanding achievements at the 8th International Conference on Photosynthesis and Hydrogen Research for Sustainability at the University of Hyderabad in 2017. The plaque was presented by the author on behalf of the conference organizers during the closing ceremony

was Volume 20) is a must read for anyone interested in the history of plant science.

In 1983, Govindjee was approached by Mr. Ad Plaizier (of Martinus Nijhoff/Dr. Junk) to take up the editing of Photosynthesis Research. His service as an editor is praiseworthy since during his tenure as Chief Editor, the number of pages increased fourfold from $\sim 400$ to $\sim 1600$ pages per year (Govindjee et al. 2002). Govindjee has also taken a particular interest in recognizing and honoring both established and young scientists. This led to Govindjee establishing a History \& Biography section of the journal. The Govindjee et al. (2006) book (Volume 20, mentioned above) is the culmination and integration of 111 articles from this Historical Corner of the journal, with 132 authors (from 19 countries), many being the discoverers themselves.

In addition to the above service, Govindjee has coauthored many Tributes and News Reports honoring both young and established scientists (see Appendix 1 for a list of Tributes, and Appendix 2 for many News Reports; also see http://www.life.illinois.edu/govindjee/recent_papers.html, for more). In a similar vein along with A.S. Raghavendra of the $\mathrm{UoH}$, Govindjee honored one of the greatest scientists of India, Sir Jagdish Chandra Bose (Raghavendra and Govindjee 2011).

I conclude this short summary of Govindjee's outstanding contributions to photosynthesis by highlighting the Govindjee and Rajni Govindjee Award for Excellence in Biological Research given each year at UIUC (Fig. 3; also see http:// www.life.illinois.edu/govindjee/photooftheyear2018.html). Govindjee's 85th birthday, on October 24, 2017, was also the 60th wedding anniversary of Govindjee and Rajni who married while $\mathrm{PhD}$ students in the laboratory of Robert Emerson (1903-1959). Rajni also went on to a long career at UIUC, first in photosynthesis and then she subsequently worked on the molecular mechanism of proton transport in bacteriorhodopsin from Halobacterium halobium (see Ebrey 2015). The Govindjee and Rajni Govindjee Award for Excellence in Biological Research was established in 2006 to support expenses for graduate students at UIUC for conducting research in any aspect of Plant Biology and Biochemistry (see http://sib.illinois.edu/graduate/grants/Govindjee). The awardees are listed in Appendix 3.

The reader will lean a great deal about Govindjee's career from his own account in his informal personal perspective of research (Govindjee 2018). Among his many research accomplishments, Govindjee pioneered the first picosecond measurements on Photosystem I and Photosystem II primary photochemistry and he established the unique role of bicarbonate on the acceptor side of Photosystem II; in addition, he provided the first comprehensive theory of thermoluminescence in algae and plants and made great strides in using delayed and prompt fluorescence to understand both photosynthetic electron 


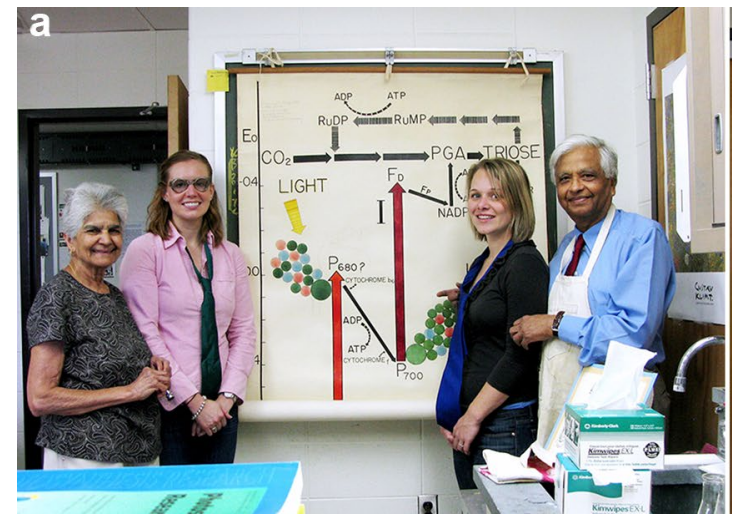

Fig. 3 Govindjee and Rajni Govindjee with Awardees at UIUC. a Left to right: Rajni Govindjee; Courtney Leisner [2012 Govindjee and Rajni Govindjee Awardee (wearing Robert Emerson's glasses that he wore when he did glass blowing)]; and the late Sharon Gray (2012 Govindjee and Rajni Govindjee Awardee); and Govindjee (wearing Emerson's laboratory apron). The poster in the photograph is the 1964-1965 Z-Scheme designed by Govindjee and made by

transport and photoprotection against excess light. These achievements and much more are discussed in an excellent interview by Don Ort, a colleague of many years at UIUC, who conducted it on behalf of Annual Reviews, Inc (https ://www.youtube.com/watch? $\mathrm{v}=\mathrm{cO}$ ZuL0vxEi0). Govindjee's web page is also an excellent source of information on photosynthesis and his outstanding career (http://www. life.illinois.edu/govindjee/).

On behalf of everyone in the photosynthesis community and beyond who have benefitted from Govindjee's commitment to science-and his ceaseless efforts to facilitate the careers of all those who cross his path-a huge Thank You to Govindjee Govindjee (your new formal name since 2018) for all that you have done for us.

Funding The preparation of this manuscript was supported by funds provided by the Department of Biochemistry, University of Otago, New Zealand.

\section{Compliance with ethical standards}

Conflict of interest The author declares that he has no conflict of interest.

\section{Appendix 1}

\section{Tributes, coauthored by Govindjee, chronologically arranged}

Govindjee (1988) The discovery of chlorophyll-protein complex by Emil L. Smith during 1937-1941. Photosynth Res $16: 285-289$

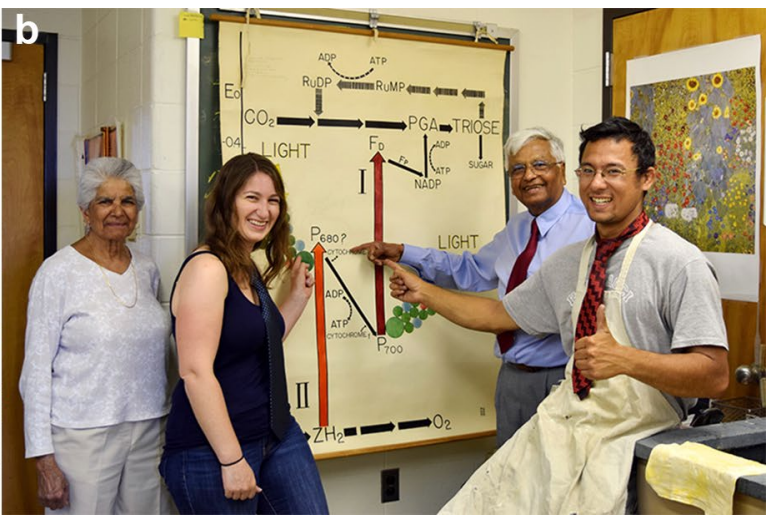

Natalie Davis. b (Left to right): Rajni Govindjee; Laura Stein (2015 Robert Emerson Awardee); Govindjee; and Darshi Banan (2015 Govindjee and Rajni Govindjee Awardee). Natalie, Govindjee and Darshi are pointing at "P680", the reaction center chlorophyll $a$ that was predicted by Govindjee to work in Photosystem II, but discovered 4 years later by Gunter Döring in 1969 in Horst Witt's Lab in Berlin. Photographs by Joan Huber

Govindjee (1989) My association with Stacey French. In: G.E. Briggs (ed.) Photosynthesis. Alan Liss Publishers, NY. pp. 1-3

Govindjee (2001) Lighting the path: A tribute to Robert Emerson (1903-1959) S-43-001. In: PS2001: Proceedings 12th International Congress on Photosynthesis (Online and CD- ISBN 0643 067116) at link (E-mail: ps2001@publish. csiro.au)

Govindjee (2004) Robert Emerson, and Eugene Rabinowitch: Understanding photosynthesis. In: Hoddeson L (editor) No Boundaries: University of Illinois Vignettes, Chap. 12, pp. 181-194. University of Illinois Press, Urbana and Chicago

Govindjee, Fork DC (2006) Charles Stacy French (1907-1995). Biographical Memoirs (National Academy of Sciences, Washington, DC) 88:2-29

Nozzolillo CG, Gorham HH, Govindjee (2007) Obituary: Paul R. Gorham (April 16, 1918—November 9, 2006). Photosynth Res 92:3-5

Govindjee (2008) Recollections of Thomas John Wydrzynski. Photosynth Res 98:13-31 (he is deceased now)

Black CC, Govindjee (2008) Martin Gibbs and the peaceful uses of nuclear radiation, C14. Photosynth Res 99:63-80

Govindjee (2009) A tribute to Achim Trebst, a friend. Photosynth Res 100:113-115

Govindjee (2010a) Obituary of Sam Aronoff. ASPB (American Society of Plant Biologists) News 37 (2) 21-22

Govindjee (2010b) Celebrating Andrew Alm Benson's 93rd birthday. Photosynth Res 105:201-208

Hirsch RE, Rich M, Govindjee (2010) A Tribute to Seymour Steven Brody: In Memoriam (November 29, 1927 to May 25, 2010). Photosynth Res 106:191-199 
Hagar W, Punnett H, Punnett L, Govindjee (2011) A tribute to Thomas Roosevelt Punnett, Jr. (1926-2008). Photosynth Res 110:1-7

Fleischman D, Edwards GE, Govindjee, Mayne L, Tyagi V, Jacobsen-Mispagel K (2012) Berger C. Mayne (1920-2011): a friend and his contributions to photosynthesis research. Photosynth Res 112:81-89

Govindjee, Srivastava N (2014) William A. Arnold (1904-2001) - Biographical Memoirs. (National Academy of Sciences, Washington, DC) 18 pages; available free at: http://www.nasonline.org/memoirs

Karapetyan NV, Govindjee (2014) Alexander Abramovich Krasnovsky (1913-1993): 100th birth anniversary in Moscow, Russia. Photosynth Res 120:347-353

Choules L, Govindjee (2014) Stories and photographs of William A. Arnold (1904-2001): A pioneer of photosynthesis. Photosynth Res 122:87-95

Tiwari S, Tripathy BC, Jajoo A, Das AB, Murata N, Sane PV, Govindjee (2014) Prasanna K. Mohanty (1934-2013): a great photosynthetiker and a wonderful human being who touched the hearts of many. Photosynth Res 122:235-260

Govindjee, Frenkel S (2015) Albert W. Frenkel (1919-2015): Photosynthesis research pioneer, much-loved teacher, and scholar. Photosynth Res 124:243-247; also see ASPB (American Society for Plant Biology) News 42 (3): 29-31

Lichtenthaler HK, Buchanan BB, Douce R, Govindjee (2015) Andrew A. Benson, 1917-2015. Photosynth Res 124:131-135

Lichtenthaler HK, Buchanan BB, Douce R, Govindjee (2015) Obituary: Andrew A. Benson, 1917-2015. ASPB (American Society for Plant Biology) News, March/April, 2015: pp. 25-26

Govindjee, Prince RC, Ort DR (2015) Memoir: Colin A. Wraight, November 7, 1945 July 10, 2014. Photosynthetica 53:478-480

Govindjee, Prince RC, Ort DR (2016) Colin A. Wraight, 1945-2014. Photosynth Res 127: 237-256

Maroti P, Govindjee (2016) The two last overviews by Colin Allen Wraight (1945-2014) on energy conversion in photosynthetic bacteria. Photosynth Res 127: 257-271

Nonomura A, Lorimer G, Holtz B, Vacquier V, Biel KY, Govindjee (2016) Andrew A. Benson: Personal recollections. Photosynth Res 127:369-378

Govindjee, Bassham H, Bassham S (2016) Remembering James Alan Bassham (1922- 2012). Photosynth Res 128:3-13

Elchuri SV, Govindjee (2016) Vallabhaneni Sita Rama Das, 1933-2010: Teacher and mentor. Photosynth Res 128:109-115

Huseynova IM, Allakhverdiev SI, Govindjee (2016) Jalal A. Aliyev (1928-2016): A great scientist, a great teacher and a great human being. Photosynth Res 128: 219-222
Govindjee, Pulles MPJ (2016) Louis Nico Marie Duysens (March 15, 1921-September 8, 2015): A leading biophysicist of the twentieth century. Photosynth Res 128:223-234

Govindjee, Marcelle D (2016) René Marcelle (December 30, 1931-December 18, 2011), the first editor-in-chief of Photosynthesis Research. Photosynth Res 129:13-15

Buchanan BB, Douce R, Govindjee, Lichtenthaler HK, Summons RE (2016) Andrew Alm Benson, 1917-2015, Biographical Memoirs. (National Academy of Sciences, Washington, DC) 16 pages, available at http://www.nason line.org/memoirs

Brand JJ, Kerfeld CA, Cramer WA, Govindjee (2017) David W. Krogmann, 1931-2016. Photosynth Res 132:1-12

Yurina NP, Popov VO, Krasnovsky Jr. AA, Govindjee (2017) Remembering Navasard V. Karapetyan (1936-2015). Photosynth Res 132:221-226

Govindjee, Munday JC, Jr, Papageorgiou GC (2017) Frederick Yi-Tung Cho (1939-2011): His PhD days in biophysics, the Photosynthesis Lab, and his patents in engineering physics. Photosynth Res 132:227-234

Govindjee (2017) André Tridon Jagendorf (1926-2017). Photosynth Res 132:235-243

Latimer MG, Bannister TT, and Govindjee (2017) Paul Henry Latimer (1925-2011): Discoverer of selective scattering in photosynthetic systems. Photosynth Res 134:83-91

Nonomura AM, Holtz B, Biel KY, Cooney R, Lorimer G, Govindjee (2017) The paths of Andrew A. Benson: a radio-autobiography. Photosynth Res 134:93-105

Allakhverdiev SI, Zharmukhamedov SK, Rodionova MV, Shuvalov VA, Dismukes C, Shen J-R, Barber J, Samuelsson G, Govindjee (2018) Vyacheslav (Slava) Klimov (1945-2017): A scientist par excellence, a great human being, a friend, and a Renaissance man. Photosynth Res 136:1-16

Herbert SK, Siderer Y, Govindjee (2018) Shmuel Malkin (1934-2017) Listening to photosynthesis and making music. Photosynth Res 137:1-15

Govindjee, Tanner W (2018) Remembering Otto Kandler (1920-2017) and his contributions. Photosynth Res; https://doi.org/10.1007/s11120-018-0530-z

Naithani S, Govindjee (2018) Remembering Professor Prasanna K. Mohanty (April 1, 1934 - March 9, 2013). Current Plant Biology (in the press): https://doi. org/10.1016/j.cpb.2018.05.002 [I t is an article on Mohanty's 5th death anniversary]

Laws E, Weidemann A, Hoch G, Bannister H, Knox RS, Govindjee (2018) In memory of Thomas Turpin Bannister (1930-2017). Photosynth Res, in the press: PRES-D-18-00168 


\section{Appendix 2}

\section{News Reports (and more), coauthored by Govindjee, recognizing young scientists (see ${ }^{*}$ ) as well as senior scientists, arranged chronologically}

Govindjee (2001a) Our greetings to Olle Bjorkman, Christopher Field and Alexander Glazer. Photosynth Res 70:241-243

Govindjee (2001b) Calvin and Hill Prizes. Photosynth Res 70:325-328 [The Calvin prize was awarded to Krishna Niyogi, and the Hill prize was awarded jointly to Petra Fromme and Norbert Krauß]

Govindjee, Gest H (2002) Editorial: Celebrating the millennium - historical highlights of photosynthesis research. Photosynth Res 73:1-6

Govindjee, J.T. Beatty JT, Gest H (2003) Editorial: Celebrating the millennium - historical highlights of Photosynthesis Research, Part 2. Photosynth Res 76:1-11

Govindjee, Allen JF, Beatty JT (2004) Celebrating the millennium-historical highlights of Photosynthesis Research, Part 3. Photosynth Res 80:1-13

Govindjee, Krogmann DW (2004) Discoveries in oxygenic photosynthesis (1727-2003): A perspective. Photosynth Res 80:15-57

Govindjee (2006) Editorial: Celebrating 20 years of historical papers in Photosynthesis Research. Photosynth Res 87:151-158

Govindjee Krogmann D (2006) Discoveries in Oxygenic photosynthesis (1727-2003): A perspective. Chemistry and Biology: the Transition Between the Two Centuries. Accademia Nazionale dei Lincei, pp. 204-256

*Govindjee, Rutherford AW, Britt RD (2007) Four young research investigators were honored at the 2006 Gordon research conference on photosynthesis. Photosynth Res 92:137-138

*Govindjee, Telfer A (2007) Six young research investigators were honored at an international conference in Russia. Photosynth Res 92:139-141

Govindjee (2009a) List of biography and history published mostly in Photosynthesis Research, 1988-2008. Photosynth Res 99:139-153

* Govindjee (2009b) Young research investigators honored at the 2008 and 2009 Gordon research conference on photosynthesis: ambiance and a personal perspective. Photosynth Res 102:1-6

*Govindjee, Ananyev GM, Savikhin S (2011) Young research investigators honored at the 2011 Gordon research conference on photosynthesis: ambiance and a perspective. Photosynth Res 110:143-149

Portis AR Jr, Govindjee (2012) William L. Ogren was honored with a Lifetime Achievement Award by the
Rebeiz Foundation for Basic Research. Photosynth Res 110:213-220

* Moore G, Ananyev G, Govindjee (2012) Young research investigators honored at the 2012 Gordon research conference on photosynthesis. Photosynth Res 114:137-142

Allakhverdiev, S. I., Tomo, T., and Govindjee (2014) International conference on "Photosynthesis research for sustainability-2014: in honor of Vladimir A. Shuvalov", held on June 2-7, 2014, in Pushchino, Russia. Photosynth Res 122:337-347

*Rappaport F, Malnoe A, Govindjee (2015) Gordon research conference on photosynthesis: from evolution of fundamental mechanisms to radical re-engineering. Photosynth Res 123:213-223

*Govindjee, Grossman AR, Bhaya D (2016) Gordon research conference on the dynamics and regulation of photosynthesis: From the origin of bio-catalysis to innovative solar conversion. Photosynth Res 127:379-389

Allakhverdiev SI, Tomo T, Stamatakis K, Govindjee (2016) International Conference on "Photosynthesis research for sustainability-2015 in honor of George C. Papapageorgiou", September 21-26, 2015, Crete Greece. Photosynth Res 130:1-10

*Gisriel C, Saroussi S, Ramundo S, Fromme P, Govindjee (2017) Gordon Research Conference on photosynthesis: photosynthetic plasticity from the environment to synthetic systems. Photosynth Res 136:393-405

Govindjee, Redding K (2017) Honoring Jean-David Rochaix. Photosynth Res 131:221-225

Tsygankov AA, Allakhverdiev SI, Tomo T, Govindjee (2017) International conference on Photosynthesis Research for Sustainability-2016: In honor of Nathan Nelson and Turhan Nejat Veziroglu. Photosynth Res 131:227-223

\section{Appendix 3}

The Govindjee and Rajni Govindjee Award for Excellence in Biological Research was established in 2006 to support expenses for graduate students at the University of Illinois at Urbana-Champaign for conducting research in any aspect of Plant Biology and or Biochemistry; it is administered by the School of Integrative Biology (SIB), and the School of Molecular and Cell Biology (MCB).

The awardees are:

2007: Sanjeewa Rupasinghe

2008: Cecile M. Sano; and Kelly M. Anderson

2009: Maheshi Dassanayake

2010: Ryan Kelly; Kelly Gillespie; and Brian Steidinger 2011: R.J. Cody Markelz

2012: Courtney Leisner; and Sharon Gray ${ }^{\#}$ (1985-2016) ("https://sib.illinois.edu/remembering/sharon_gray/) 
2013: Robert (Bob) Koester; Adriana Corrales Osorio; Samantha Primer; Rebecca (Becky) Slattery, and Robert Van Buren.

2014: Rodney L. Burton

2015: Darshi Banan

2016: William Arnold

2017: Ingrid Carolina Romero Valero

2018: Daniel Bruce Raudabaugh; and Logan Robert Hurst

\section{References}

Allakhverdiev SI, Shen J-R, Edwards GE (eds) (2013) Special issues on Photosynthesis Education honoring Govindjee. Photosynth Res 116:107-110

Clegg RM (2012) Contributions of Govindjee, 2000-2011. In: EatonRye JJ, Tripathy BC, Sharkey TD (eds) Photosynthesis: plastid biology and carbon assimilation. Advances in photosynthesis and respiration, vol 34. Springer, Dordrecht, pp 835-844

Demmig-Adams B, Garab G, Adams III, Govindjee WW (eds) (2014) Non-photochemical quenching and energy dissipation in plants, algae and cyanobacteria. In: Advances in photosynthesis and respiration, vol 40. Springer, Dordrecht

Eaton-Rye JJ (2007a) Celebrating Govindjee's 50 years in photosynthesis research and his 75th birthday. Photosynth Res 93:1-5

Eaton-Rye JJ (2007b) Snapshots of the Govindjee lab from the late 1960 s to the late 1990s. and beyond.... Photosynth Res 94:153-178

Eaton-Rye JJ (2012) Contributions of Govindjee, 1970-1999. In: Eaton-Rye JJ, Tripathy BC, Sharkey TD (eds) Photosynthesis: plastid biology, energy conversion and carbon assimilation. Advances in photosynthesis and respiration, vol 34. Springer, Dordrecht, pp 815-834

Eaton-Rye JJ (2013) Govindjee at 80: more than 50 years of free energy for photosynthesis. Photosynth Res 116:111-144

Eaton-Rye JJ (2018) Foreword to a special issue, celebrating Govindjee's 85 th birthday. Photosynthetica 56:1-10

Eaton-Rye JJ, Tripathy BC, Sharkey TD (eds) (2012) Photosynthesis: plastid biology, energy conversion and carbon assimilation. Advances in photosynthesis and respiration, vol 34. Springer, Dordrecht, p 856

Ebrey T (2015) Brighter than the sun: Rajni Govindjee at 80 and her fifty years in photobiology. Photosynth Res $124: 1-5$

Garab G (2018) Our gratitude and congratulations to our guest editor Julian Eaton-Rye and thanks to all the 167 contributors to the special issue honoring professor Govindjee. Photosynthetica 56:1235-1236

Govindjee (ed) (1975) Bioenergetics of photosynthesis. Academic Press, New York

Govindjee (ed) (1982a) Photosynthesis. Volume I. Energy conversion by plants and bacteria. Academic Press, New York
Govindjee (ed) (1982b) Photosynthesis. Volume II. Development, carbon metabolism and plant productivity. Academic Press, New York

Govindjee, Coleman W (1990) How plants make oxygen. Sci Am 262:50-58

Govindjee, Govindjee R (1974) Primary events in photosynthesis. Sci Am 231:68-82

Govindjee (2018) A sixty-year tryst with photosynthesis and related processes: an informal personal perspective. Photosynth Res. https ://doi.org/10.1007/s11120-018-0590-0

Govindjee, Amesz J, Fork DC (eds) (1986) Light emission by plants and bacteria. Academic Press, Orlando

Govindjee, Sestak Z, Peters WR (2002) The early history of "photosynthetica", "photosynthesis research" their publishers. Photosynthetica 40:1-11

Govindjee, Beatty JT, Gest H, Allen JF (eds) (2006) Discoveries in photosynthesis. In: Advances in photosynthesis and respiration, vol 20. Springer, Dordrecht

Itoh S, Mohanty P, Guruprasad KN (eds) (2015) Dedication. In: Photosynthesis: basics to application. I. K. International Publishing House Pvt. Ltd, New Delhi, p v

Jajoo A, Guruprasad KN, Bharti S, Mohanty P (2009) International conference "Photosynthesis in the Global Perspective" held in honor of Govindjee, November 27-29, 2008, Indore, India. Photosynth Res 100:49-55

Papageorgiou GC (2012) Contributions of Govindjee, 1955-1969. In: Eaton-Rye JJ, Sharkey TD, Tripathy BC (eds) Photosynthesis: plastid biology and carbon assimilation. Advances in photosynthesis and respiration, vol 34. Springer, Dordrecht, pp 803-814

Papageorgiou GC (2015) Foreword. In: Itoh S, Mohanty P, Guruprasad KN (eds) Photosynthesis: basics to application. I. K. International Publishing House Pvt. Ltd, New Delhi pp vii-xiv

Papageorgiou GC, Govindjee (eds) (2004) Chlorophyll $a$ fluorescence: a signature of photosynthesis. Advances in photosynthesis and respiration, vol 19. Springer, Dordrecht

Prášil O (2014) Govindjee, an institution, at his 80th (really 81st) birthday in October 2013: a pictorial essay. Photosynth Res 122:113-119

Rabinowitch E, Govindjee (1965) The role of chlorophyll in photosynthesis. Sci Am 213:74-83

Rabinowitch E, Govindjee (1969) Photosynthesis. Wiley, New York

Raghavendra AS, Govindjee (2011) Sir Jagadish Chandra Bose (1858-1937): a pioneer in photosynthesis research and discoverer of unique carbon assimilation in Hydrilla. In: Raghavendra AS, Sage RF (eds) C4 Photosynthesis and related $\mathrm{CO}_{2}$ concentrating mechanism. Advances in photosynthesis and respiration, vol 32. Springer, Dordrecht, pp 3-11

Shevela D, Björn LO, Govindjee (2018) Photosynthesis: solar energy for life. World Scientific, Singapore

Soni V (2018) Govindjee: the biologist extraordinary. J Plant Sci Res $34: 117-118$

Soni V, Kaur P (2018) News report: National symposium on photosynthesis and felicitation function for professor Govindjee. J Plant Sci Res 34:115-116 